\title{
RANCANGAN PROGRAM PELATIHAN KARAKTER KREATIF PADA MAHASISWA UNIVERSITAS NEGERI JAKARTA
}

\author{
Dwi Kencana Wulan* \\ * Universitas Negeri Jakarta
}

DOI: https://doi.org/10.21009/JPPP. 082.03

\author{
Alamat Korespondensi: \\ kencana.wulan@gmail.com
}

\begin{abstract}
Creative ideas are not only generated from creative thinking, but also need to be supported by individual creative character (nonaptitude creativity). This study aims to obtain data about problems in developing creative characters in students. The results showed aspects of creative characters that still need to be developed are high curiosity, like challenges and dare to take risks. Based on this we design a training program to develope creative character. This training program focuses on providing learning through direct experienced, in order to develop aspects high curiosity, like challenges and dare to take risks of students
\end{abstract}

Keywords: Creativity, Creative Character and Students

\section{Pendahuluan}

Generasi keempat atau industri 4.0 ialah sistem siber fisik (cyber physical system), dengan digitasi dan interkoneksi produk, rantai nilai (value chains) dan model bisnis. Industri 4.0 juga mencakup riset, jejaring pelaku industri, dan standardisasi (Ritonga, 2019). Kehadiran industri 4.0 bukan tanpa kelemahan. Berdasarkan analisis SWOT dari 'Digital Transformation Monitor', faktor kelemahan industri 4.0 ialah potensi akan berkurangnya tenaga kerja pada level bawah atau pelaksana. Penerapan industri 4.0 memang memerlukan prasyarat SDM berkualitas. Bahkan, kesempatan kerja berpendidikan rendah di sektor industri secara keseluruhan diperkirakan akan kian terbatas mengingat percepatan arus barang dan jasa dari produsen ke konsumen pada gilirannya memacu kegiatan industri mengaplikasikan teknologi maju (Ritonga 2019).

Pertumbuhan dan percepatan di era Industri 4.0 memicu munculnya reaksi-reaksi dan opini dari para pelaku usaha di Indonesia, salah satunya adalah seorang pengusaha terkenal di Indonesia yaitu Chairul Tanjung. Ia berpendapat bahwa inovasi dan kreativitas merupakan kunci utama dunia usaha dalam menghadapi revolusi industri 4.0. Kompetensi sumber daya manusia (SDM) di era revolusi industri 4.0 memerlukan upaya pengembangan transformasi pendidikan yang sesuai dengan kebutuhan dunia kerja saat ini. Menteri Perindustrian Airlangga Hartato menyampaikan pendapatnya pada acara Creative Industries Movement, bahwa Industri 4.0 mendorong pemerintah untuk melakukan empowering human talents, yaitu suatu upaya yang dilakukan untuk memperkuat generasi muda dengan teknologi dan inovasi. Menperin menilai, generasi milenial sangat berperan penting dalam menerapkan industri 4.0. Terlebih lagi, Indonesia akan menikmati masa bonus demografi hingga tahun 2030. Artinya, sebanyak 130 juta jiwa yang berusia produktif dapat mengambil kesempatan baru untuk mengembangkan bisnis di era digital (Kementrian Perindustrian Republik Indonesia, 2019).

Salah satu sumber daya manusia yang berperan penting dalam mencapai keberhasilan Indonesia pada sektor industri dan perekonomian di era Industri 4.0 adalah mahasiswa. Mahasiswa 
diharapkan akan mampu mengaplikasikan ilmu dan pengetahuan yang diperoleh di pendidikan tinggi guna memenangkan perasaingan di dunia kerja. Berdasarkan pemaparan pengusaha Chairul Tanjung dan Menteri Perindustrian Indonesia sebelumnya, inovasi dan k reativitas menjadi kunci keberhasilan memenangkan pertarungan di dunia kerja, khususnya di era Industri 4.0. Untuk itu mahasiswa diharapkan dapat mengembangkan aspek kreativitas dan kemampuan inovasi yang dimiliki selain memperdalam pengetahuan dan ilmu sesuai bidang kajian yang dijalani.

Pada penelitian sebelumnya, mengenai kreativitas pada mahasiswa Universitas Negeri Jakarta, peneliti mendapatkan gambaran bahwa kreativitas sangat dibutuhkan oleh mahasiswa baik saat mereka menjalani pendidikan di perguruan tinggi maupun untuk menjalani persaingan di dunia kerja di masa mendatang. Pada penelitian tersebut juga diperoleh gambaran bahwa kegiatan belajar yang diterapkan di tingkat pendidikan tinggi seperti di Universitas atau perguruan tinggi menuntut mahasiswa untuk lebih mandiri dalam berpikir guna menyelesaikan persoalan-persoalan dan tugas yang diberikan. Tujuan belajar di tingkat pendidikan tinggi pada umumnya mengutamakan pengaplikasian konsep dasar yang sudah dipahami dan dipelajari mahasiswa dalam menganalisa persoalan yang berkaitan dengan materi yang dipelajari, sehingga tidak lagi menekankan pada pemahaman dan mengingat serta mengulang materi saja. Oleh karena itu mahasiswa diharapkan mampu memecahkan permasalahan dengan cermat dan menghasilkan solusi yang tepat serta bervariasi. Proses berpikir ini membutuhkan produktivitas ide yang banyak dan kelancaran dalam berpikir. Gambaran tersebut menjelaskan bahwa mahasiswa membutuhkan proses berpikir kreatif yang dapat menunjang kegiatan belajarnya, sehingga mahasiswa mampu beradaptasi dengan baik terhadap tuntutan-tuntutan yang dihadapi.

Guilford menjelaskan terdapat empat aspek berpikir kreatif, yaitu: kelancaran berpikir, fleksibelitas berpikir, orisinal dan elaborasi. Keempat aspek ini sangat dibutuhkan oleh individu untuk menyelesaikan persoalan-persoalan yang dihadapi, baik dalam bidang akademik maupun di kehidupan sehari-hari. Selain itu, dapat membantu individu untuk menciptakan karya-karya kreatif yang orisinal dan baru. Dengan demikian kreativitas merupakan kemampuan untuk dapat berpikir dengan lancar, fleksibel, orisinal dan mampu untuk mengelaborasi dalam menghasilkan ide-ide dengan cepat, banyak, bervariasi, baru, kaya dan rinci dalam menghadapi setiap persoalan yang datang (Guilford, 1970).

Produk kreatif akan dapat dihasilkan dari proses berpikir kreatif pada individu, yang ditunjang oleh sifat kreatif atau ciri-ciri afektif dari individu tersebut yang berkaitan erat dengan keinginan dan dorongan seorang untuk terus menghasilkan ide-ide pemikiran yang kreatif. Ciri-ciri afektif atau karakter kreatif yang dimaksud yaitu: memiliki rasa ingin tahu yang besar, imajinatif, suka tantangan, berani mengambil resiko dan memiliki sifat menghargai (Guilford, 1970). Rasa ingin tahu yang besar diwujudkan dalam perilaku-perilaku yang selalu mempertanyakan sesuatu, senang mengetahui sebab atau alasan dari setiap kejadian, seringkali mengamati dan memperhatikan orang, objek dan situasi disekitarnya. Sifat imajinatif dapat terlihat dari perilaku individu yang senang mengandaiandai tentang sesuatu yang belum pernah terjadi sebelumnya, namun tetap dapat membedakan antara khayalan dan kenyataan. Individu yang menyukai tantangan dapat terlihat dari perilaku-perilakunya yang selalu ingin menyelesaikan persoalanpersoalan sulit yang akan membuatnya merasa tertantang, sehingga mendorong individu tersebut untuk megembangkan sikap tidak mudah menyerah dan gigih.

Sifat kreatif selanjutnya adalah berani mengambil resiko, hal ini dapat terwujud dari perilaku-perilaku individu yang selalu ingin mencoba hal-hal baru, tidak takut mengalami kegagalan serta berani menghadapi situasi yang tidak pasti atau belum memiliki kejelasan (unconventional). Sifat seperti ini akan mendorong individu untuk selalu mencari ide-ide baru dan melihat permasalahan dari sudut pandang yang berbeda-beda, sehingga dapat menemukan penyelesaian masalah yang tepat untuk persoalan yang dihadapi. Cara atau pola yang digunakan berbeda-beda, sehingga individu tersebut akan terus menggali dan mendapatkan pola berpikir yang baru. Sifat menghargai juga perlu dikembangkan dengan alasan bahwa seorang yang kreatif dan mampu menghasilkan karya kreatif harus tetap menghargai diri sendiri dan orang lain. Individu kreatif yang mampu menghargai akan tetap berusaha menghasilkan ide-ide kreatif yang berguna dan 
memiliki manfaat positif bagi diri sendiri, orang lain dan lingkungan.

Berdasarkan hasil penelitian sebelumnya diperoleh gambaran karakter kreatif mahasiswa Universitas Negeri Jakarta, diperoleh data bahwa terdapat $67 \%$ responden mahasiswa UNJ yang telah mengembangkan sifat kreatifnya dengan cukup optimal. Selanjutnya $18 \%$ responden mahasiswa UNJ memiliki sifat kreatif pada kategori tinggi, yang menunjukkan pengembangan sifat kreatif yang sudah optimal. Sedangkan 15\% lainnya memiliki sifat kreatif yang tergolong rendah. Hal ini menunjukkan bahwa mereka belum mengembangkan sifat kreatifnya dengan optimal. selain itu diperoleh data yang menunjukan bahwa 562 responden berada dalam kategorisasi skor sedang untuk masing-masing dimensi, dimensi yang memiliki kategorisasi skor tinggi paling banyak adalah dimensi 2 yaitu aspek imajinatif sedangkan dimensi yang memiliki kategorisasi skor rendah yang paling sedikit adalah dimensi 1 yaitu rasa ingin tahu yang tinggi. (Dwi, 2018).

\section{Metode Penelitian}

Penelitian ini menggunakan research and development yang terdiri dari tiga tahapan, yaitu pendahuluan, pengembangan, dan implementasi. Tahap Pendahuluan terdiri dari analisis kebutuhan. Tahap pengembangan terdiri dari perencanaan, produksi tahap awal, uji coba awal, revisi produk utama, uji coba lapangan utama, revisi produk operasional, uji lapangan operasional dan revisi produk final. Populasi dalam penelitian ini adalah mahasiswa aktif Universitas Negeri Jakarta. Penelitian ini menggunakan teknik pengambilan sampel berupa purposive sampling. Purposive sampling adalah penentuan sampel yang sesuai dengan karakteristik yang ingin diteliti. Jumlah sampel pada penelitian ini berjumlah 638 orang.

Pada penelitian ini, teknik pengumpulan data dilakukan dengan menggunakan kusioner karakter kreatif, yang disusun sendiri oleh peneliti berdasarkan konsep kreativitas dari Guilford. Instrumen ini terdiri dari 77 butir item. Berdasarkan hasil uji coba diperoleh nilai validitas yang berada pada rentang 0,3 sampai 0,7 dengan reliabilitas masing-masing dimensi secara berutan rasa ingin tahu yang tinggi, imajinatif, suka tantangan, berani mengambil resiko, sifat menghargai adalah 0,756 ; 0,$618 ; 0,782 ; 0,699 ; 0,940$.

\section{Hasil Penelitian dan Diskusi}

Berdasarkan dari hasil penelitian yang diperoleh, diketahui bahwa subjek penelitian yang dilakukan terdiri dari 638 responden dengan jenis kelamin laki-laki 298 responden dan jenis kelamin perempuan 340 responden. Responden yang berpartisipasi pada penelitian ini memiliki usia 17 26 tahun.

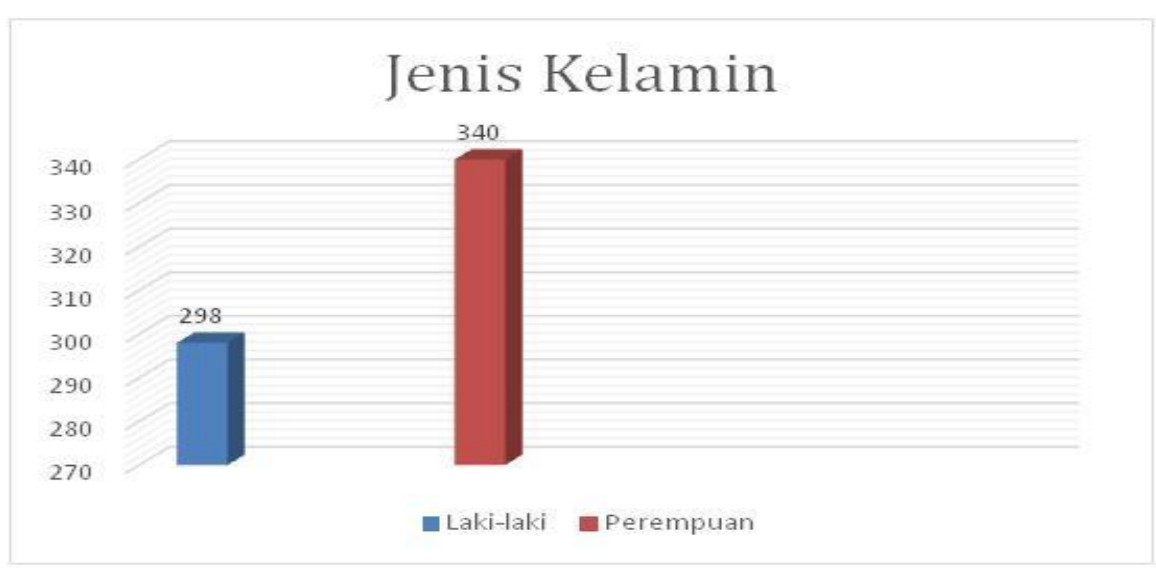

Gambar 1. Gambaran Responden Berdasarkan Jenis Kelamin

Berdasarkan Fakultas terdapat 48 orang yang berasal dari Fakultas Ilmu Pendidikan, 61 orang dari Fakultas Ekonomi, 107 orang dari Fakultas Bahasa dan Seni, 164 orang dari Fakultas
Pendidikan Psikologi, 79 orang dari Fakultas Ilmu Olahraga, 47 orang dari Fakultas Ilmu Sosial, 77 orang dari Fakultas Teknik dan 55 orang dari Fakultas Matematika dan IPA. 


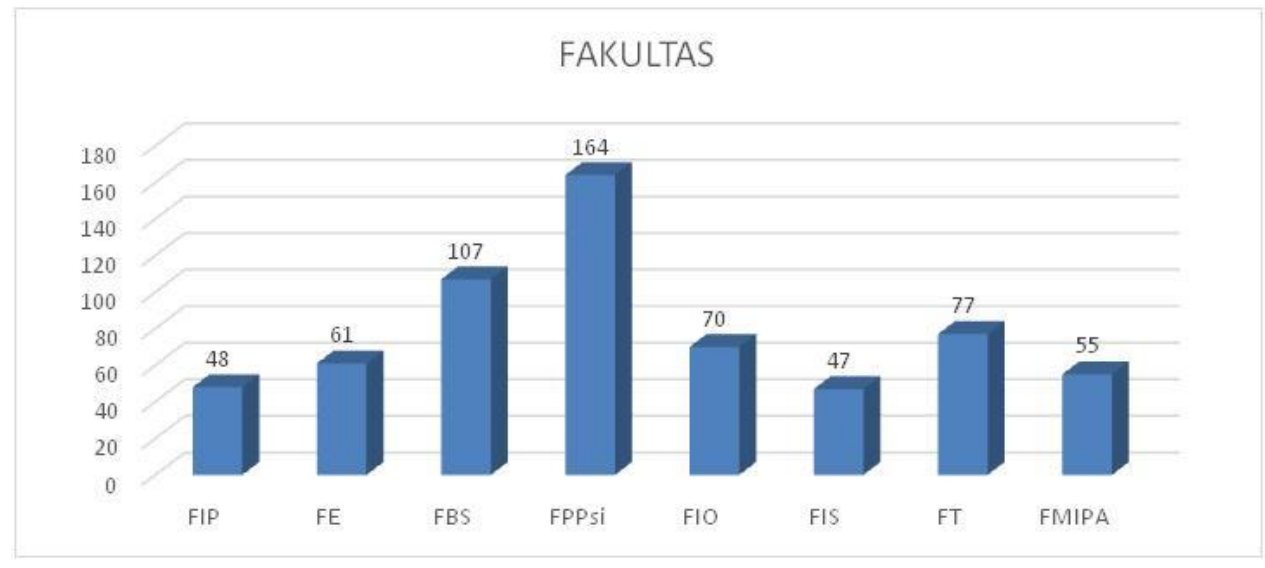

Gambar 2. Gambaran Responden Berdasarkan Fakultas

Berdasarkan semester yang sedang ditempuh terdapat 232 orang yang sedang berada di semester 2, 90 orang sedang berada di semester 3 ,
137 orang berada di semester 4,18 orang berada di semester 5,144 orang yang berada di semester 6 , 10 orang berada di semester 8,2 orang berada di semester 10 dan 1 orang berada di semester 12 .

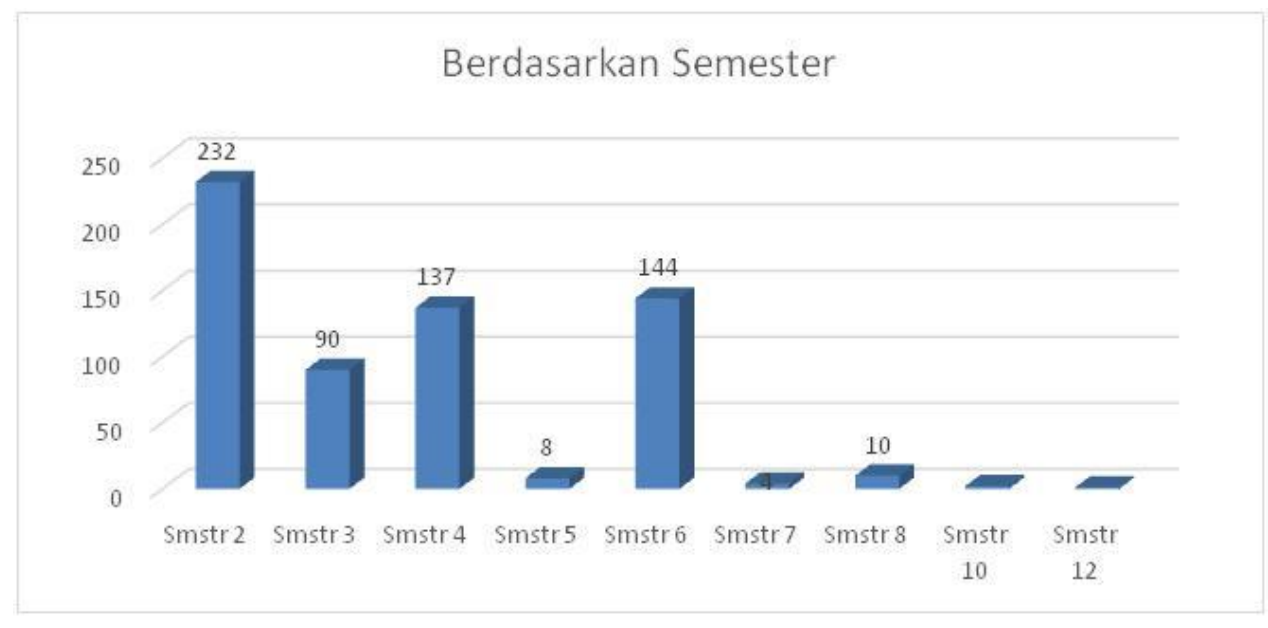

Gambar 3. Gambaran Responden Berdasarkan Semester

Gambar 3 menunjukkan hasil data bahwa 638 responden berada dalam kategorisasi skor sedang untuk masing-masing dimensi, dimensi yang memiliki kategorisasi skor tinggi paling banyak adalah dimensi 2 yaitu aspek imajinatif sedangkan dimensi yang memiliki kategorisasi skor rendah yang paling sedikit adalah dimensi 1 yaitu rasa ingin tahu yang tinggi. 


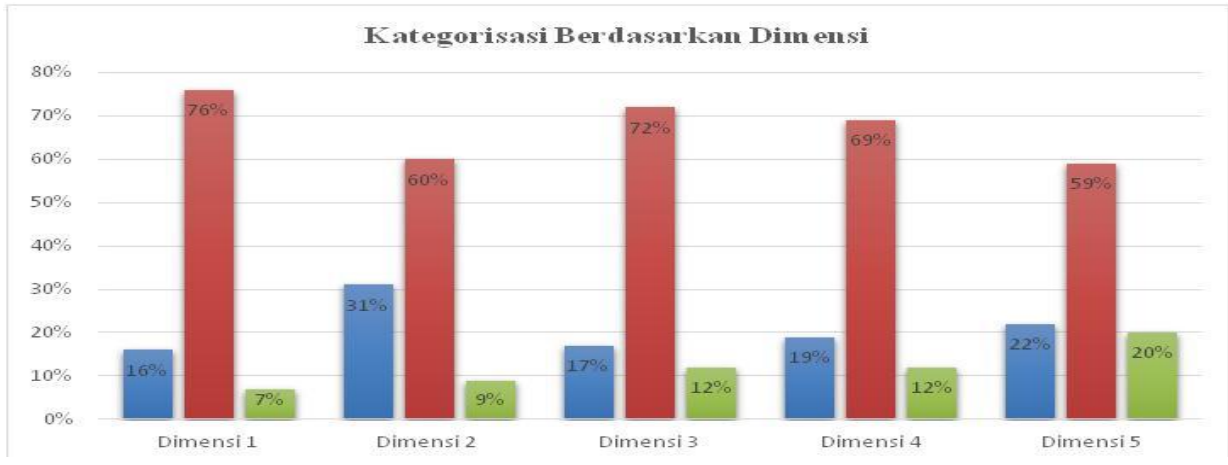

Gambar 4. Gambaran Responden Berdasarkan Dimensi Karakter

Kreatif

Pada bagian sebelumnya telah dijelaskan bahwa untuk menghasilkan karya yang kreatif tidak hanya diperoleh dari hasil berpikir kreatif, namun juga ditunjang dengan sifat kreatif yang baik. Sifat kreatif yang ditelusuri pada penelitan ini, terdiri dari lima sifat yaitu, rasa ingin tahu yang tinggi, imaginatif, menyukai tantangan, berani mengambil resiko dan memiliki sifat menghargai. Kelima sifat ini menjadi tolak ukur pembentukan sifat kreatif pada diri individu. Hasil penelitian menunjukkan 638 responden yang merupakan mahasiswa Universitas Negeri Jakarta, yang terdiri dari 298 laki-laki dan 340 perempuan pada umumnya memiliki sifat kreatif yang tergolong dalam kategori sedang. Hal ini menunjukkan terdapat $67 \%$ responden mahasiswa UNJ yang telah mengembangkan sifat kreatifnya dengan cukup optimal. Selanjutnya $17 \%$ responden mahasiswa UNJ memiliki sifat kreatif pada kategori tinggi, yang menunjukkan pengembangan sifat kreatif yang sudah optimal. Sedangkan 16\% lainnya memiliki sifat kreatif yang tergolong rendah. Hal ini menggambarkan bahwa mereka belum mengembangkan sifat kreatifnya dengan optimal.

Selain menggambarkan mengenai kategori sifat kreatif yang dimiliki responden, pada penelitian ini juga diperoleh data mengenai dimensi sifat kreatif yang banyak dimiliki oleh responden. Hasil penelitian menunjukkan $31 \%$ responden mahasiswa UNJ mempeoleh nilai yang tinggi untuk dimensi imajinatif.

Dimensi kedua yang menunjukkan nilai responden pada kategori tinggi (22\%) adalah dimensi sifat menghargai. Namun pada dimensi menghargai, responden yang terdiri dari mahasiswa UNJ juga memperoleh nilai terendah yang paling banyak, yaitu sebanyak 20\%. Dimensi berikutnya diperoleh $19 \%$ responden dengan kategori tinggi adalah dimensi berani mengambil resiko. Dimensi berikutnya dengan $17 \%$ responden mahasiswa UNJ yang tergolong pada kategori tinggi yaitu, menyukai tantangan.

Untuk dimensi kelima terdapat $16 \%$ dari responden mahasiswa UNJ yang memiliki sifat rasa ingin tahu pada kategori tinggi, hal ini menunjukkan sifat rasa ingin tahu yang tinggi masih belum menjadi prioritas responden untuk menunjang proses pemikiran kreatifnya dalam menciptakan suatu karya.

Pada responden penelitian ini, yang terdiri dari mahasiswa Universitas Negeri Jakarta (UNJ) dari 8 fakultas sifat rasa ingin tahu yang tinggi menjadi sifat yang masih perlu dikembangkan dengan optimal, guna menunjang perkembangan sifat kreatif mahasiswa secara keseluruhan.

\section{Kesimpulan}

Responden penelitian yang merupakan mahasiswa Universitas Negeri Jakarta masih perlu mengembangkan karakter kreatif yang dimiliki guna menunjang proses berpikir kreatifnya. Karakter kreatif yang perlu dikembangkan terutama adalah rasa ingin tahu yang tinggi, sehingga mahasiswa akan dapat memiliki keinginan untuk menelusuri informasi yang berkaitan dengan hal-hal yang ia pelajari atau temui dengan rinci, luas dan mendalam. Oleh karena itu program pelatihan karakter kreatif ini disusun secara bertahap yang didahului dengan pemberian materi yang bertujuan untuk melepaskan kecemasan yang menghambat ekspresi peserta. Kemudian terdapat sesi diskusi yang dapat membantu peserta untuk melakukan eksplorasi seluas-luasnya untuk dapat 
mempermudah peserta menemukan gagasan baru. Pada tahap selanjutnya peserta distimulasi untuk dapat mengembangkan sikap berani mengambil Tahapan ini akan diakhiri dengan penulisan karya kreatif yang orisinal dari peserta. Berdasarkan gambaran tersebut, fokus utama program pelatihan ini adalah meningkatkan karakter kreatif mahasiswa terutama pada aspek rasa ingin tahu yang tinggi, menyukai tantangan dan berani mengambil resiko.

\section{Daftar Pustaka}

Dwi Kencana Wulan, Fitri Lestari Issom. (2018). Creative Character of Jakarta University Stundent. International Conference On University and Intellectuan Culture (hal. 203). Jakarta: Laboratorium Sosial Politik Press UNJ.

Fajriah, S. Q. (2014). Hubungan Antara Metakognisi dan Kreativitas pada Mahasiswa yang sedang Mengerjakan Tugas Akhir di Jurusan Arsitektur Universitas Diponegoro. Empati, 3, 610618.

Guilford, J.P. Creativity : Retrospect and Prospect. Journal of Creativity Behavior. . 1970. 4,3. 149-168

Marsudi, I. (2007). Pembelajaran Berbasis Kreativitas untuk Meningkatkan Pencapaian Kompetensi Mahasiswa Bidang Aplikasi Komputer. Pendidikan Teknologi dan Kejuruan, 16, 19-40. resiko dan menyukai tantangan dengan mempertimbangkan kemampuan yang dimiliki.

Munandar, U. (1999). Mengembangkan Bakat dan Kreativitas Anak Sekolah. Jakarta : Grasindo.

Munandar, U. (2004). Pengembangan Kreativitas Anak Berbakat. Jakarta : Rineka Cipta.

Perindustrian, K. (2019, April). www.kemenperin.go.id. Dipetik April 2, 2019

Pratitis, N. T. (2018). Hubungan Antara Kemampuan Visual-Spasial dengan Kreativitas pada Mahasiswa Prodi Arsitektur. Persona: Jurnal Psikologi Indonesia, 7, 215-223.

Ritonga, R. (2019, Maret 01). Industri Kreatif di Era Industri 4.0. Dipetik April 04, 2019, dari Media Indonesia: http://www.mediaindonesia.com

Shodik, J. (2019, Januari 18). www.indopos.co.id. Dipetik April 4, 2019

Stenberg, R. J. (2007). Wisdom, Intelligence, and Creativity Synthesized. New York: Cambridge University Press.

Sugiyono. (2006). Metode Penelitian Pendidikan. Pendekatan Kuantitatif, Kualitatif, dan R\&D. Bandung: Penerbit Alfabeta.

Vernon, P.E. 1973. Creativity. Victoria: Penguin Education 